\title{
Garcia da Orta in Goa: pioneering tropical medicine
}

\begin{abstract}
Ivan A D'Cruz
Cholera made an impressive reappearance this year in South America, continuing a pandemic that started 30 years ago in Indonesia and then passed through Asia, the Middle East, southern Europe, Africa, and Japan. This dramatic comeback makes it appropriate to commemorate the man who published the first "modern" description of severe "Asian" cholera. Four and a quarter centuries ago, in 1563, Garcia da Orta's Coloquios dos simples e drogas e cousas medicinais da India was printed in Goa, the Portuguese colony on the west coast of India. It was the third book ever printed in Asia, and the first on a non-religious subject. It was the earliest foundation for the science of tropical medicine and materia medica, as taught in European

tained botanical gardens in which he grew medicinal herbs for his own professional use as well as for commercial sale, both in Goa and in Bombay.

As personal physician to people high in Portuguese governmental and ecclesiastical hierarchies in Goa, da Orta remained protected from the clutches of the Goan branch of the Inquisition, which was as suspicious and predatory toward "new Christians" as was its Iberian counterparts. However, a year after Garcia da Orta's death his sister Catarina was burnt at the stake "as an impenitent Jewess," and in 1580 da Orta's own remains were exhumed and burnt in an auto-da-fé at Goa as posthumous punishment for being a crypto-Jew during life.
\end{abstract} universities, where it continued to be used as an authoritative text for the next two or three centuries, and it long predated the important therapeutic advances made by illustrious members of the British and French colonial medical services.

Da Orta practised medicine and studied pharmacognosy in Goa continuously from 1534 until his death there in 1568. Portugal was then at the height of its sea power and colonial glory, and Goa was its eastern jewel, a splendid city basking in the centre of east-west trade (fig 1).

Garcia da Orta's parents were "new Christians" of Jewish origin, who had fled the Spanish Inquisition to the town of Castelo de Vide in Portugal. Young Garcia studied arts, philosophy, and medicine at the Spanish universities of Salamanca and Alcala de Henares from 1515 to 1523 . After spending the years 1526 to 1534 on the faculty of Lisbon University he made an adventurous career move, sailing for Goa in March 1534 in a fleet commanded by Martin Affonso de Sousa, who later (1542-5) became governor general of Portuguese Asia.

Among his patients da Orta had a succession of governors and viceroys of Goa, one of whom granted him a long lease on the island of Bombay, which was then a Portuguese possession amounting to little more than a fishing village. Da Orta developed and main-

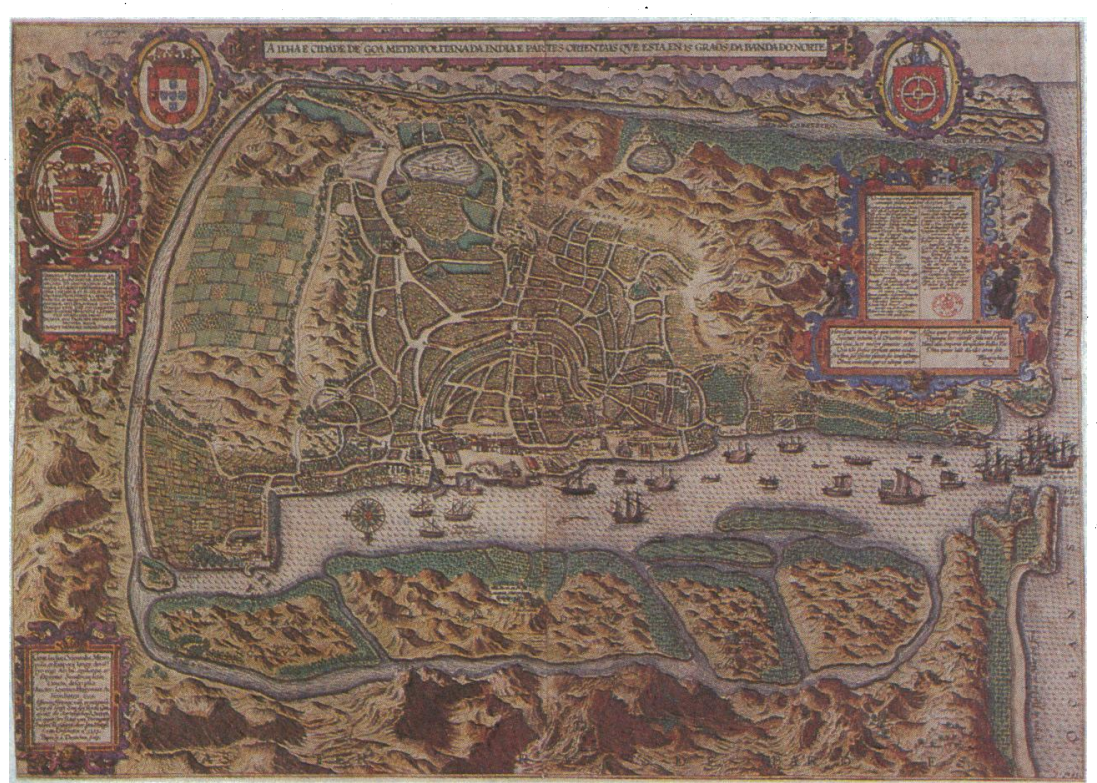

FIG 1-Goa in the sixteenth century, a bustling trading city and outpost of Portuguese power

\section{A remarkable book}

In addition to its historical place in tropical medicine and materia medica, da Orta's monumental Coloquios is remarkable in some other ways. It had more typographical errors than any other printed volumethe errata ran to 20 closely printed pages, ending with the statement, "There are many other misprints in the book." Also, it begins with the earliest published poem of Luis de Camoens, Portugal's greatest literary son, who met and conversed with da Orta while staying in Goa.

The Portuguese physician-historian Dr Augusto da Silva Carvalho located 14 copies of this book extant in 1934. The diligent research of C R Boxer, Camoens professor of Portuguese at King's College, London, yielded nine more, though some were in poor or incomplete condition. No copies are known to exist in Goa itself. Coloquios was written in the form of a dialogue between da Orta, a pioneer scientist who spoke from his own systematic observations, and a hypothetical $\mathrm{Dr}$ Ruano, a learned graduate of Salamanca but new to the tropics, who quotes the old classical medical views and theories of Dioscorides, Galen, Pliny, etc. The Coloquios comprised 59 chapters, each devoted to a different "remedy." Some of these, such as opium and cannabis, have continued to be topics of pharmacological interest; others would now be categorised as spices (nutmeg, cardamom, cinnamon, cloves, ginger) or edible fruits (mangoes, coconuts, melons).

Much of all this is not relevant to clinical medicine as we now know it. However, da Orta's description of Asiatic cholera is so true and complete that it deserves to be quoted as a classic: "The pulse is very weak and can scarcely be felt. The skin is very cold, with some sweat, also cold. The patient complains of great heat and a burning thirst. The eyes are much sunken, and he cannot sleep. There is continued retching and diarrhoea until he is unable to discharge anything There is also cramp in the legs. ... It generally proves fatal within 24 hours. I have known a patient who lasted no longer than 10 hours, and those who last longest live for four days."

Cholera was so named and referred to by Celsus in Roman times, but it is generally acknowledged that Asiatic cholera, with its fulminant course and serious prognosis, was first brought to the attention of European medicine by da Orta. Carolus Clusius (15261609), a peripatetic Flemish physician, came across a 


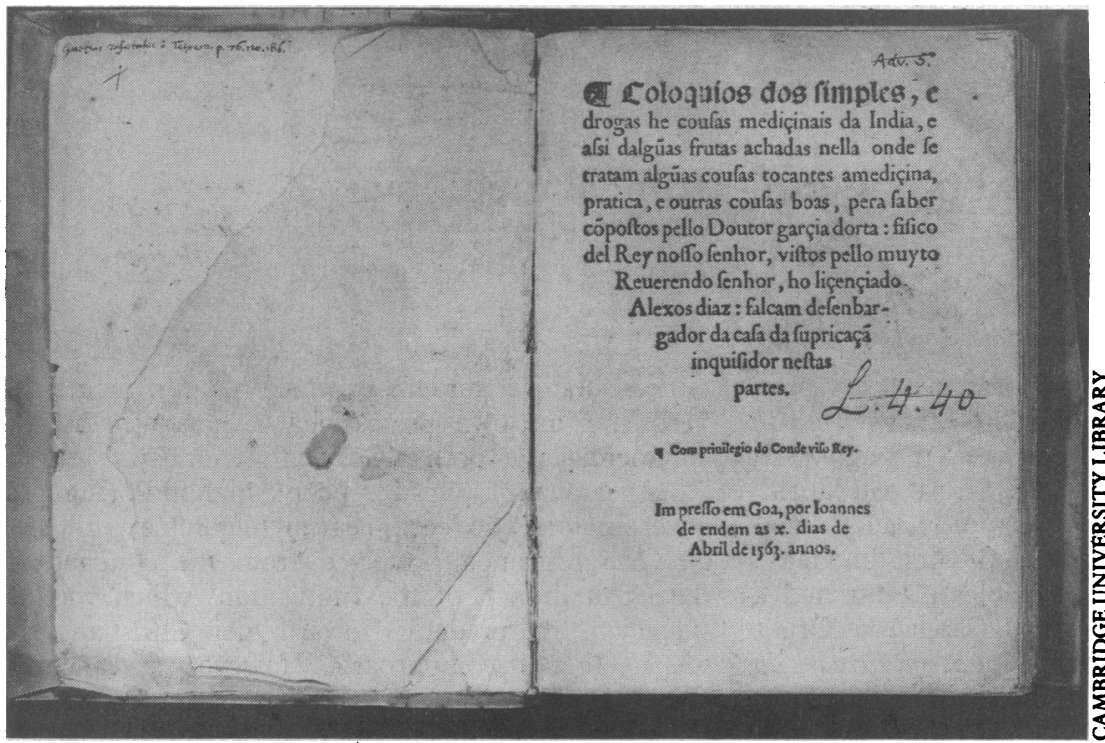

FIG 2-The Flemish physician

Clusius used the copy of the

"Colloquios" now in Cambridge

University library to prepare a Latin version that was used in European universities for the next two centuries copy of da Orta's Coloquios in Lisbon the year after its publication in Goa. He translated it into Latin; he also edited, annotated, and abridged it, trimming it of nonmedical and anecdotal digressions. The new version, published in Antwerp in 1567, was titled Aromatum et Simplicium Aliquot Medicamentorum Apud Indios Nascentiun Historia. It achieved great popularity in European universities, ran into five editions in Clusius's lifetime, and is the form in which da Orta's original work was chiefly disseminated for the next two centuries. Clusius's own copy of the da Orta book, as originally published in Portuguese - autographed, dated (1564), and copiously annotated by the Flemish physician - lies in the Cambridge University library (fig 2). ${ }^{2}$

\section{Staying on in Goa}

Garcia da Orta did not accompany his patron Affonso de Sousa back to Portugal, nor did he retire there to enjoy a prosperous old age, as did most colonials then and since. His decision to remain in Goa may have been due to political or religious exigencies, ${ }^{3}$ but also perhaps to the fact that the lush verdant beauty of Goa had him in its spell. The picturesque beaches, ancient temples, and cosy villages with their pretty parish churches-all interlaced by drowsy, palm fringed roads - have changed little in the four centuries since my own ancestors inhabited a Goan village across the Mandovi River from where da Orta practised and Portuguese viceroys and inquisitors ruled. Nothing remains of the magnificent city of old Goa but half a dozen huge, empty (but well preserved) sixteenth century churches, one of which contains the mummified body of St Francis Xavier in a massive tomb of incredible splendour.

Garcia da Orta himself has been commemorated in twentieth century Goa (now part of India) not by tomb, bust, or statue but by a small public garden in an unfrequented nook of Panjim, the state's capital.

1 Behren RH. Cholera. BMF 1991;302:1039-40.

2 Levine MM. South America: the return of cholera. Lancet 1991;338:45-6.

3 Boxer CR. Two pioneers of tropical medicine: Garcia d'Orta and Nicholos Monardes. London: Wellcome Historical Medical Library, 1963:25. (Lecture series No 1.)

\section{Goya's living skeleton}

\section{Richard H R Park, Maureen P Park}

The case of Joseph Merrick, "the elephant man," publicised the Victorians' craving for callous entertainment and curiosity. ${ }^{1}$ Less well known is a group of emaciated individuals exhibited at shows and circuses under the descriptive term of "living skeleton." One of the most celebrated was Claude Ambroise Seurat, the subject of a drawing by the Spaniard Francisco Goya (1746-1828) (fig 1). Goya's lifelong fascination for freaks of nature, demons, and monsters was not diminished by old age. He was 82 years old when, in 1826 at a circus in Bordeaux, he encountered Seurat, "el esquelete vibiente."

The previous year Seurat's visit to London had aroused much controversy. ${ }^{3}$ Though he was an instant success with the public who flocked to see him, several members of the medical establishment in London voiced their disgust at the commercial exploitation of Seurat. Because of this publicity there is an extensive, though incomplete, account of Seurat's life. ${ }^{34} \mathrm{He}$ was born in Troyes in the department of Champagne, France, on 10 April 1797. At birth, after an uncomplicated pregnancy, he seemed healthy and normal. From early childhood, however, "as the infant grew, the frame gradually wasted away"; at the age of 10 Seurat was "as healthy as other children, except that his chest was depressed, and he was much weaker"; by the age of 14 his frame "dwindled away to the skeleton form." There had been no history of inherited disease in his family. In 1825, aged 28, he was 5 feet 7 inches tall $(170 \mathrm{~cm})$ and weighed 78 pounds $(35.5 \mathrm{~kg})$.

From the summary of the clinical findings (probably by Sir Astley Cooper), recorded fully in Hone's Every
Day Book and from the accompanying drawings by George Cruikshank (fig 2) it is apparent that Seurat had major skeletal abnormalities which were most likely congenital in origin. Firstly, he had very noticeable pectus excavatum: "the sternum is much flattened, as though it had been driven inwards towards the dorsal vertebra, or back-bone... it scarcely leaves more than one and a half inches, or two inches between itself and the opposite vertebra." Secondly, the heart was misplaced: "the heart is observed pulsating very low down behind the 7th, 8th and 9th ribs in the situation of the left hypochondrium... Sir Astley Cooper finds his heart is placed so much out of the common region allotted to it, that it is precisely its own length lower than if properly placed." ${ }^{.4}$ Thirdly, Seurat had a bilateral scapular deformity: "the peculiar form and situation of the scapulae, the upper angles of which instead of laying on the posterior portions of the ribs are turned over the shoulder, and pass so far forward as nearly to reach the middle of the clavicles, where their situation may be easily seen from before... the muscles called levatores scapulae pass very much outwards towards the shoulder joint, and from their size and turgidity, have the appearance of bones." Lastly, he appeared to have brevicollis: "the neck appears short, flat and broad.".

Contemporary physicians regarded Seurat as a case of "marcores, an early obliteration of the lacteal vessels and mesenteric glands." ${ }_{3}$ There is, however, little evidence for malabsorption, and the emaciation would seem to have been as result of a grossly inadequate oral intake of food due to dysphagia: "in eating he masti- 